\title{
Cointegration Analysis of Tourism Sector, Inflation, Interest Rate and Economic Growth in a Special Autonomy Region of Aceh Province, Indonesia
}

\author{
Dzakiyy Hadiyan Achyar*1, Dedi Budiman Hakim ${ }^{2}$ \\ ${ }^{*}$ School of Economics, Faculty of Economics and Management, Institut Pertanian Bogor, IPB Dramaga, \\ Bogor 16680, Indonesia \\ ${ }^{2}$ Departement of Economics, Faculty of Economics and Management, Institut Pertanian Bogor, IPB \\ Dramaga, Bogor 16680, Indonesia
}

\begin{abstract}
Article Info

Volume 8 Issue 1

Page Number: 216-221

Publication Issue :

January-February-2021

This study is aimed at examining the cointegration relationship of tourism spending, inflation, interest rate, and economic growth. In addition, the correction measure is conducted to measure the tourism spending, inflation, interest rate, and economic growth trend are sustainable in Special Autonomy Province of Aceh, Indonesia between 1990 - 2019. Data from Indonesian Statistics Agency and Central Bank of Indonesia was used in this study. Johansen integration test figures out long run equilibrium of the analysed variables. Augmented Dickey Fuller test figures out that all variables are stationary at first difference. The result provides the evidence that there is one cointegrating relationship maintained. The result shows the long-term relationship of economic growth, tourism spending, inflation, and interest rate, where the null hypothesis is rejected with a statistical trace, and one vector equation co-integrates with the Max-Eigen statistical. This study recommends that policymakers should maintain low rate of inflation and constant level of interest rate.
\end{abstract}

\section{Article History}

Accepted : 01 Jan 2021

Published : 10 Jan 2021
Keywords : Cointegration Relationship, Correction Measure, Johansen Integration, Augmented Dickey Fuller Test, Vector Equation, Max-Eigen Statistical

\section{INTRODUCTION}

Economic growth is a vital and long-term economic performance indicator worth achieving in pursuit of nation's welfare. Basically, economic growth is growth of output per capita in the long run. If the economy is growing, the production level of goods and services rises within the economy. Rising production leads to rising income obtained by society. Then, the output growth enables people to consume higher number of goods and services or known as greater purchasing power in society. Economic growth is a single dimension indicator which is measured by rising production and income indicated by rising Gross Domestic Product (GDP). This 
indicator is helpful to measure the degree of success for policy that is implemented on macro scale.

Nevertheless, higher inflation often occurs in a rapid growing economy as a consequences of aggressive capital inflow that stimulates higher level of economic activities including rising production, distribution, and consumption. Usually, this phenomenon will elevate the level of minimum wages that could raise society's welfare. However, a rising inflation would also elevate the prices of goods and services that would alleviate people's purchasing power. Therefore, level of inflation is supposed to be maintained in a certain level that is still ideal for targeted level of economic growth.

In order to maintain the level of inflation, the Central Bank frequently applies monetary policies such as the interest rate. Interest rate is a useful policy to control the average saving and investment in the economy. Higher interest rate will lead to higher cost of borrowing as people will choose to save more to gain benefits from rising interest rate. Consequently, the money supply that causes inflation will decline but at the same time the investment level will decline as well.

Certainly, changes in the money supply is not only caused by inflation and interest rate. Government spending in large scale sector such as tourism sector will rises the investment level in the economy and will likely influence the economic growth. Moreover, rises in human capital, physical capital, and natural resources can significantly accelerate the economic growth. Obviously, tourism sector that utilizes great number of human capital, physical capital, and natural resources can give large economic impacts to the region. Lodging, restaurants, transportation, amusements, and souvenir stores in tourism area will employ large number of human capital, physical capital, and natural resources to generate their profits.
Simultaneously, more jobs can be created, more tax revenues can be gained, and more income can be distributed among society. Therefore, intensified efforts are executed by the Aceh government to attract more tourists as tourism sector has become a main priority that can effectively accelerate the economic growth. Tourism sector has been proven to be reliable in providing significant contribution and strategic role in improving economic development, area development, and society welfare. Throughout times, tourism sector in Aceh do not experience significant decline amid global economic crises. Therefore, tourism sector is considered as vital factor in economic development and a vital invisible export that can strengthen the balance of payments due to increasing level of goods and services export reflected by rising amount of acquired foreign currency. Therefore, desired economic growth will be easier to be attained by managing suitable level of relevant variables that affect the tourism sector, inflation, interest rate, and other financial condition controlled by banks as they play significantly within the economy (Saxena et al., 2018).

\section{METHODS AND MATERIAL}

An important assumption in a Least Square method is the independent variable has a constant and restricted variance (stationary). However, this assumption is difficult to be fulfilled in time series research as it has constant upward or downward trend (non-stationary). Another important assumption is that there must be no correlation between independent variable and residual component.

This assumption is frequently difficult to be fulfilled if the independent variable is time series due to nonstationarity characteristic. Therefore, a cointegration regression is employed to overcome the condition. The necessity term is that the variables are on similar integration level. The sufficiency term is the residual must be stationary. Thus, variables that are cointegrated are located on long run equilibrium. 
Cointegration test uses the Johansen (1988) formula, which is in accordance with the maximum likelihood and likelihood ratio statistical tests measured by trace test or maximum Eigen test value:

Maximum Eigenvalue Statistic Test:

$$
\lambda_{\max }(\bar{r})=-T \ln \left(1-\lambda_{j+1}\right)
$$

A'priori Expectation:

$\begin{array}{ll}\mathrm{EG} t=\alpha 0+\beta 1 \mathrm{INF}_{\mathrm{t}}+\beta 2 \mathrm{IR}_{\mathrm{t}}+\beta 3 \mathrm{TOU}_{\mathrm{t}}+\mathrm{et} \\ \mathrm{EG} & : \text { economic growth } \\ \mathrm{INF} & : \text { inflation } \\ \mathrm{IR} & : \text { interest rate } \\ \text { TOU } & : \text { tourism spending } \\ \alpha & : \text { a constant } \\ \beta 1, \beta 2, \beta 3 & : \text { the regression } \\ \text { coefficient e } & : \text { disturbance. }\end{array}$

\section{RESULTS AND DISCUSSION}

The cointegration test in table 2 shows a Statistical Trace with a vector equation that co-integrates at a $5 \%$ significance level and a max-eigenvalue statistic, as well as the results of a vector equation, cointegrated at a significant level of 5\%. This shows the long-term relationship of Economic Growth, Tourism Spending, Inflation, and Interest Rate, where the null hypothesis is rejected with a statistical trace, and one vector equation co-integrates with the Max-Eigen statistical.

As shown by the table, Trace statistics is lower than $5 \%$ Critical Value at more than one cointegrating equation $(24.6816<29.68)$, therefore, the null hypothesis is accepted. Thus, there is maximum rank of one cointegrating equation only. In other words, the variables of Economic Growth, Tourism Spending,
Inflation and Interest Rate all are co integrated into one and possess long-run association and moving together in the long run.

\section{A. ADF Stationarity Test}

Unit root examination is used to avoid false regression from time-series observation started from 1990 to 2019. The unit root test results use the Augmented Dickey- Fuller (ADF) method.

\section{TABLE 1. ADF STATIONARITY TEST}

\begin{tabular}{|c|c|c|c|c|}
\hline Variables & $\begin{array}{l}\text { Unit Root } \\
\text { Test }\end{array}$ & $\begin{array}{l}\text { ADF } \\
\text { Test } \\
\text { Statistics }\end{array}$ & $\begin{array}{l}\text { Critical } \\
\text { Value } \\
\mathbf{5 \%} \\
\end{array}$ & Information \\
\hline \multirow[t]{2}{*}{$\begin{array}{l}\text { Economic } \\
\text { Growth }\end{array}$} & Level I(0) & 1.574 & -3.500 & $\begin{array}{l}\text { Non- } \\
\text { stationary }\end{array}$ \\
\hline & $\begin{array}{l}\text { First } \\
\text { Difference } \\
\text { I(I) }\end{array}$ & -12.707 & -3.448 & Stationary \\
\hline \multirow[t]{2}{*}{$\begin{array}{l}\text { Tourism } \\
\text { Spending }\end{array}$} & Level I(0) & -1.400 & -3.448 & $\begin{array}{l}\text { Non- } \\
\text { stationary }\end{array}$ \\
\hline & $\begin{array}{l}\text { First } \\
\text { Difference } \\
\text { I(I) }\end{array}$ & -6.513 & -3.448 & Stationary \\
\hline \multirow[t]{2}{*}{ Inflation } & Level I(0) & -3.254 & -3.452 & $\begin{array}{l}\text { Non- } \\
\text { stationary }\end{array}$ \\
\hline & $\begin{array}{l}\text { First } \\
\text { Difference } \\
\text { I(I) }\end{array}$ & -7.257 & -3.448 & Stationary \\
\hline \multirow[t]{2}{*}{$\begin{array}{l}\text { Interest } \\
\text { Rate }\end{array}$} & Level I(0) & -2.858 & -3.448 & $\begin{array}{l}\text { Non- } \\
\text { stationary }\end{array}$ \\
\hline & $\begin{array}{l}\text { First } \\
\text { Difference } \\
\text { I(I) }\end{array}$ & -4.788 & -3.448 & Stationary \\
\hline
\end{tabular}

Table 2 shows that economic growth, tourism spending, inflation, and interest rate are not stationary at level I (0) because the critical value > ADF test value significant at $5 \%$. Therefore, it needs to be done on the first difference I (I). The stationary test of economic growth, tourism spending, inflation, and interest rate on the first difference I (1) shows the $\mathrm{ADF}$ value $>$ of the critical value at the levels of $5 \%$. Therefore, the four variables are stationary in first difference.

Thus, all variables do not possess constant and restricted variance (stationary) characteristic on the level as they have constant upward or downward 
trend (non- stationary). However, all variables are on similar integration level (first difference). Then with the cointegration test, these variables that are cointegrated are located on long run equilibrium.

\section{B. Cointegration Test}

The series are cointegrated based on Johansen cointegration test which exhibits long run relationship and that the series could be set in a linear equation. It also implies that short run-shocks may affect the movements of the individual variables but there will be long convergence. Then, the estimation continues to assess the long run relationship by using VECM since there is a cointegrating equation.

\section{TABLE 2 COINTEGRATION TEST}

\begin{tabular}{|l|l|l|l|l|}
\hline $\begin{array}{l}\text { Maximum } \\
\text { Rank }\end{array}$ & $\lambda$ Trace & $\begin{array}{l}0.05 \\
\text { Critical } \\
\text { Value }\end{array}$ & $\lambda$ Max & $\begin{array}{l}0.05 \\
\text { Critical } \\
\text { Value }\end{array}$ \\
\hline None* & 58.1110 & 47.21 & 33.4294 & 27.07 \\
\hline 1 & 24.6816 & 29.68 & 15.6981 & 20.97 \\
\hline 2 & 8.9835 & 15.41 & 7.4827 & 14.07 \\
\hline
\end{tabular}

The series are cointegrated based on Johansen cointegration test which exhibits long run relationship and that the series could be set in a linear equation. It also implies that short run-shocks may affect the movements of the individual variables but there will be long convergence. Then, the estimation continues to assess the long run relationship by using VECM since there is a cointegrating equation.

\section{Granger Causality Test}

The Granger causality test as presented in table 3 is carried out to assess the causality direction among economic growth, tourism spending, interest rate and inflation. Thus, tourism spending Granger causes the economic growth, economic growth Granger causes the inflation, and inflation Granger causes the interest rate. In the short run, inflation does not have significant causal effect on economic growth, tourism spending has significant causal effect on economic growth at 10 percent level of significance, and interest rate does not have significant causal effect on economic growth.

\section{Impulse Response Function}

Thus, one standard deviation shock or innovation to economic growth will temporarily increases the inflation rate in the long run. The increases in inflation will not reveal until the third period. Beyond period three, the rate of inflation rises above its steady state value and

remains in the positive region. In other words, shocks to economic growth will have a positive impact on inflation rate in the long run. One standard deviation shock or innovation to interest rate will temporarily increases the economic growth in the long run. The increases in economic growth will not reveal until the third period. Beyond period three, the economic growth rises above its steady state value and remains in the positive region.

In other words, shocks to interest rate will have a positive impact on economic growth in the long run. One standard deviation shock or innovation to tourism spending will temporarily decreases the economic growth in the long run. The decreases in economic growth will not reveal until the third period. Beyond period three, the economic growth rises above its steady state value and remains in the positive region. In other words, shocks to tourism spending will have a negative impact on economic growth in the long run. 


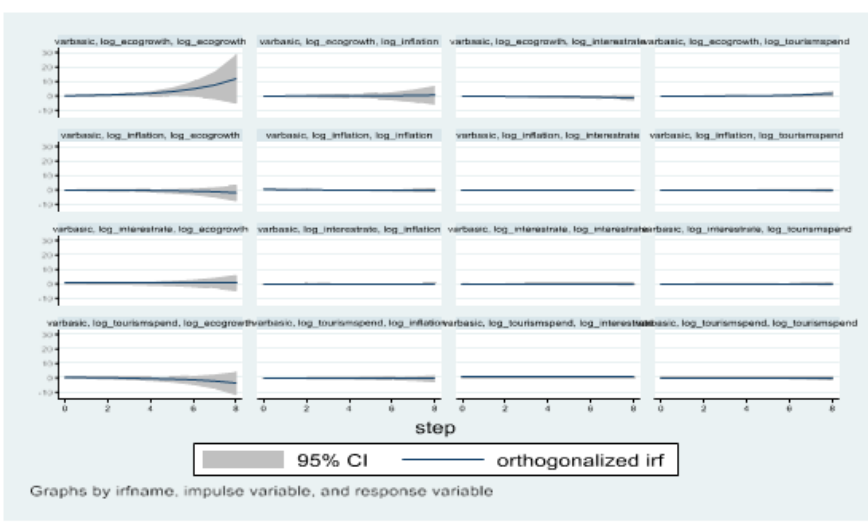

Figure $1:$ Impulse Response Function

In short term, tourism spending negatively affect the GDP growth in Aceh during this period of observation. Large investment in tourism sector has led to declining budget allocation for small-medium enterprises and manufacturing sectors which decreases these sectors' production included in GDP. However, in the longer run, return on investment in tourism sector will start to contribute to the GDP. The adjustment term (0.031) indicates that errors or deviation from long run equilibrium of economic growth will be adjusted in current year at adjustment speed of $(1-0.031) \times 100 \%=96.9 \%$

In short term, inflation negatively affects the tourism spending in Aceh. Inflation will decrease the value of money from time to time including value of investment in tourism sector spent by the government. Therefore, tourism spending must be allocated to generate higher return on investment or at least equal to the inflation rate in order to avoid the investment deficit. The adjustment term (0.002) indicates that errors or deviation from long run equilibrium of tourism spending will be adjusted in current year at adjustment speed of (1-0.002) x 100\% $=99.8 \%$

In short term, interest rate negatively affects the inflation. The monetary policy of raising interest rate is implemented by the Central Bank to reduce the money supply to alleviate the impact of inflation towards the economy. The adjustment term (0.019) indicates that errors or deviation from long run equilibrium of inflation will be adjusted in current year at adjustment speed of (1-0.019) x 100\% $=98.1 \%$

In short term, GDP growth is negatively related to the interest rate. Higher GDP growth will elevate confidence of money lenders such as banks to alleviate their interest rate (money cost of borrowing) towards their investors. Hence, lower interest rate will enable more money circulating within the economy to lead even higher GDP growth. The adjustment term (0.0018) indicates that errors or deviation from long run equilibrium of interest rate will be adjusted in current year at adjustment speed of $(1-0.0018) \times 100 \%=99.82 \%$

\section{REFERENCES}

[1]. Alhowaish, A. (2016), 'Is Tourism Development Sustainable Economic Growth Strategy in the Long Run? Evidence from GCC Countries', Journal of Sustainability, Department of Urban and Regional Planning, University of Dammam.

[2]. Inyiama, I. (2013), 'Does Inflation Weaken Economic growth? Evidence from Nigeria', European Journal of Accounting Auditing and Finance Research, vol. 1, pp. 139-150.

[3]. Johansen, S. (1988), 'Statistical analysis for cointegration vectors'. Journal of Economic Dynamics and Control, vol. 12(2- 3), pp.231-254.

[4]. K. E. \& R. C. F. Case. (2007). 'Prinsip - Prinsip Ekonomi',Penerbit Erlangga, Vol. 39, no. 5.

[5]. N. G. Mankiw. (2010). 'Macroeconomics', Worth Publishers.

[6]. Quantifying the Economic Impact of Aviation in Dubai, Oxford Economics.(2014). viewed 24 October

$2020,<$ https://www.oxfordeconomics.com/recent - releases/quantifying-the-economic-impact-ofaviation-in-dubai>

[7]. Rakhra, H.K. .(2018). 'Study on factors influencing employee retention in companies', Int. J. Public Sector Performance Management, Vol. 4, No. 1, pp.57-79. 
[8]. Saxena, N. and Taneja, M. (2018). 'A study on CRM effectiveness in public and private sector banks', Int. J. Public Sector Performance Management, Vol. 4, No. 1, pp.45-56.

[9]. Saymeh, F \& Orabi A. (2013)., 'The Effect of Interest Rate, Inflation Rate, GDP, on Real Economic Growth Rate in Jordan', Asian Economic and Financial Review, vol. 3, no.3,pp. 341- 354.

[10].Udoka, C, .(2000).,'Community banking as a catalyst for Rural economic transformation in Nigeria', International Journal of Social Science and Public Policy, vol. 3, no.2, pp. 175-182

\section{Cite this article as :}

Dzakiyy Hadiyan Achyar, Dedi Budiman Hakim, "Cointegration Analysis of Tourism Sector, Inflation, Interest Rate and Economic Growth in a Special Autonomy Region of Aceh Province, Indonesia", International Journal of Scientific Research in Science, Engineering and Technology (IJSRSET), Online ISSN : 2394-4099, Print ISSN : 2395-1990, Volume 8 Issue 1, pp. 216-221, January-February 2021. Available at doi : https://doi.org/10.32628/IJSRSET218144 Journal URL : https://ijsrset.com/IJSRSET218144 